\title{
JILBAB SEBAGAI IBADAH (STUDI FENOMENOLOGI PADA POLISI WANITA POLRES BAUBAU)
}

\author{
Adheyatul Fitry \\ Abd. Halim Talli \\ Rahmatiah HL \\ Program Pascasarjana UIN Alauddin Makassar \\ fitryadhelya@gmail.com
}

\begin{abstract}
Abstrak: Dalam hukum Islam, pemakaian jilbab wajib bagi muslimah. Setiap pemakainya didasari beberapa motivasi, satu diantaranya ibadah sebagai motivasi utama. Berdasarkan perintah teks-teks suci al-Qur'an dan al-Sunnah maka pelaksanaanyapun bernilai ibadah. Jilbab berada pada posisi sesungguhnya yang telah dilegitimasi pemakaiannya, juga sebagai kehormatan dan kemuliaan bukan untuk menjatuhkan kemanusiaan dan menurunkan martabat, justru bagi Polwan menambah energik baru, professional dalam berdinas, mampu meningkatkan kinerja dan tetap melalukan pelayanan dengan baik. Peraturan Kapolri tentang jilbab hanyalah bersifat boleh bukan suatu keharusan yang ditaati dalam lingkup kepolisian. Dari kebijakan Polri tersebut bisa dinilai bahwa para Polwan yang memakai jilbab didasari oleh kemauan sendiri yang memiliki spesifikasi alasan sebagai perintah agama terlebih tidak ada intervensi dan paksaan dari pihak manapun yang kemudian alasan memakai diikuti motivasi lain.
\end{abstract}

\section{Kata Kunci: Jilbab; Ibadah}

\section{PENDAHULUAN}

Islam sebagai panduan hidup memiliki ajaran tentang kehidupan manusia yang bermartabat sehingga manusia tetap berada pada koridor syariat. Jilbab salah satu yang diatur di dalamnya, demi terwujudnya pergaulan yang terhormat dan aman. Perempuan dengan segala aktivitasnya ingin terlihat dengan tampilan anggun juga ingin menunjukkan identitas sebagai seorang muslimah. Menurut Fedwa El-Guindi jilbab dipandang sebagai sebuah fenomena sosial yang kaya makna dan penuh nuansa. ${ }^{1}$ Dalam ranah sosial religius, jilbab berfungsi sebagai bahasa yang menyampaikan pesan sosial dan budaya. Pada awal kemunculannya, jilbab merupakan penegasan dan pembentukan identitas keberagamaan seseorang. Jilbab dapat menjadi tolok ukur tingkat kereligiusan seorang wanita. Tetapi pada perkembangannya, jilbab memiliki modernisasi yang tersembunyi. Menurut hemat peneliti, jilbab yang dianggap telah memiliki modernisasi tersembunyi tidak terlepas dari intervensi sosial karena ditegaskan bahwa perintah agama tidak bertujuan demikian, konsumer lah yang dapat menentukan pemakaian jilbab membawa penilaian ke arah positif atau sebaliknya.

${ }^{1}$ Fedwa El-Guindi, Jilbab antara kesalehan, kesopanan dan perlawanan ( Jakarta: Serambi, 2006), h. 167. 
Pemakaian jilbab merupakan hak beragama bagi Polwan tidak hanya berlaku di Aceh karena konstitusi Undang-Undang Dasar 1945 pasal 1 ayat (2) memerintahkan kepada Negara untuk memfasilitasi setiap warga Negara melaksanakan ajaran agama dengan sebaik-baiknya dan pasal 29 ayat (2). Pemenuhan unsur syariat jilbab dalam Islam dimaknai sebagai pakaian yang menutup seluruh anggota tubuh dari ujung kepala hingga ujung kaki. Dan daripada itu syarat memakai jilbab tidak tipis/transparan, tidak ketat/tidak mencetak bentuk badan, tidak berwarna mencolok dan tampilannya sederhana.

Pada masa silam, terdapat polemik jilbab di institusi kepolisian dalam penggunaan jilbab bagi Polwan saat bertugas. Permasalahan tersebut menjadi topik hangat yang diperdebatkan berbagai media massa pada Juni 2013. Permasalahan itu muncul ketika Majelis Ulama Indonesia mendapat pengaduan dari seorang Polwan yang tidak diperbolehkan mengenakan jilbab saat bertugas. Terdapat anggapan, bahwa jilbab mengganggu kinerja Polwan saat bekerja di lapangan, selain itu dalam Surat Keputusan (SK) Kepala Kepolisian Republik Indonesia (Kapolri) Nomor Pol.: Skep/ 702/IX/2005. Jilbab tidak termasuk dalam Standard Operating Procedure (SOP) seragam yang harus dipakai, dan terdapat sanksi bila melanggar peraturan tersebut. Namun pada akhirnya, perizinan penggunaan jilbab bagi Polwan mendapat titik terang. Meskipun Polwan sudah diperbolehkan memakai jilbab namun harus mengikuti aturan yang sudah ditetapkan demi terciptanya keseragaman, No. Pol.: Kep/245/II/2015 tanggal 25 Maret 2015 tentang Perubahan atas Sebagian Isi Surat Keputusan Kapolri No. Pol.: Skep/702/IX/2005 tanggal 30 September 2005 tentang Sebutan, Penggunaan Pakaian Dinas Seragam Polri dan PNS Polri, yakni bentuk dan tata cara pemakaian jilbab.

Penggunaan jilbab Polwan Baubau merupakan fenomena lokal yang berbanding lurus dengan identitas dan identifikasi dirinya. Beberapa kali sebagian Polwan Baubau merasa gembira karena jilbab dapat dipakai ketika bertugas di lingkungan Polres. Sebahagian besar Polwan memakai jilbab. Hal ini membuktikan responsifitas Polwan Baubau mengindahkan Perkap yang telah lama dinanti perizinannya.

\section{TINJAUAN TEORETIS}

\section{A. Jilbab}

Kata jilbab disebut oleh Allah swt. dalam QS al-Aḥzāb/33: 59

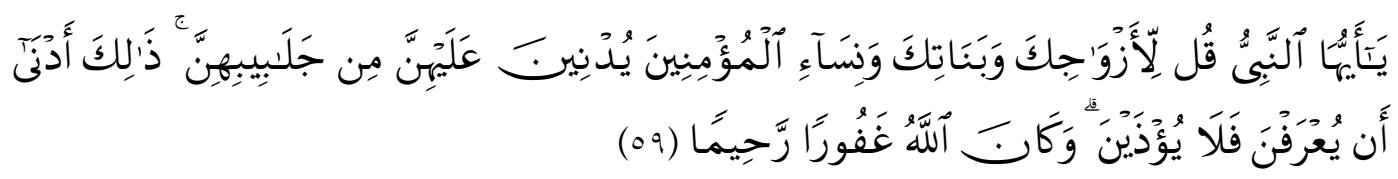

Terjemahnya:

Hai Nabi, Katakanlah kepada isteri-isterimu, anak-anak perempuanmu dan isteri-isteri orang mukmin: "Hendaklah mereka mengulurkan jilbabnya ke 
seluruh tubuh mereka". yang demikian itu supaya mereka lebih mudah untuk dikenal, karena itu mereka tidak di ganggu. dan Allah adalah Maha Pengampun lagi Maha Penyayang. ${ }^{2}$

Arti kata jilbab ketika Al-Qur'an diturunkan adalah kain yang menutup dari atas sampai bawah, tutup kepala, kain yang dipakai lapisan yang kedua oleh wanita dan semua pakaian wanita, berikut ini beberapa arti jilbab yang dikemukakan para pakar dan ulama:

1. Al-Biqo'I berpendapat bahwa jilbab adalah baju yang longgar atau atau kerudung penutup kepala wanita atau dipakai untuk menutup baju dan kerudung yang dipakainya. ${ }^{3}$

2. Syaikh Bahar Zaid juga mengatakan dalam buku Hirasatul Fadhilah, bentuk jama' dari jilbab adalah Jaläbib جَلَاِبِ atau baju kerudung yang tebal dan dikenakan oleh wanita dari kepala hingga kedua kakinya serta menutupi seluruh tubuhnya berikut pakaian dan perhiasannya. ${ }^{4}$

3. Imam Qurthubi dalam tafsirnya mengatakan bahwa jilbab berarti kain yang lebih besar ukurannya dari khimar (kerudung), sedang yang benar menurutnya jilbab adalah kain yang menutup semua badan.

4. Tafsir Ibnu Abbas : "selendang atau jilbab kudung wanita hendaklah menutupi leher dan dada agar terpelihara dari fitnah atau terjauh dari bahaya zina".

5. Dan juga dalam tafsir Ibnu Kasiir : mayoritas ulama klasik ${ }^{5}$ mengatakan bahwa jilbab adalah ar-ridā '(kain penutup) lebih besar dari kerudung.

6. Imam Ragib al-Isfahani, ahli kamus al-Qur'an yang terkenal dalam kitabnya Mu'jam Mufradat Alfaz al-Qur'an mengartikan adalah jilbab adalah baju dan kerudung.

7. Ibnu Manzur dalam karyanya Lisānul Arab, mendefenisikan jilbab adalah pakaian yang menutupi seluruh tubuh atau pakaian luar yang dikenakan di atas pakaian rumah, seperti milhafah (baju tersusun), atau pakaian luar yang digunakan untuk menutupi seluruh tubuh perempuan.

8. M. Quraish Shihab, ahli tafsir terkemuka Indonesia mengatakan bahwa aurat wanita adalah seluruh tubuhnya kecuali wajah dan kedua telapak tangannya ${ }^{6}$ namun dalam hal jilbab dan pakaian yang terpenting yang menampilkan mereka dalam bentuk terhormat. ${ }^{7}$

Kemudian dalam Ensiklopedi Hukum Islam disebutkan, jilbab adalah sejenis pakaian kurung yang longgar yang dilengkapi dengan kerudung yang

\footnotetext{
${ }^{2}$ Kementrian Agama RI, Al-Quran dan Terjemahnya (Jakarta: Samad, 2014), h. 426.

${ }^{3}$ M. Quraish Shihab, Jilbab Pakaian Wanita Muslimah; Pandangan Ulama Masa Lalu dan Cendikiawan Kontemporer (Jakarta: Lentera Hati, 2004), h. 321.

${ }^{4}$ Muhammad Muhiydin, Membela Lautan Jilbab (Yogyakarta: Diva Press, 2008), h. 21.

${ }^{5}$ Ibnu Mas'ud, 'Ubaidah, Qatadah, al-Hasan al-Bashri, Sa'id bin Jubair, Ibrahim anNakha'I, 'Atha' al-Khurasani.

${ }^{6}$ M. Quraish Shihab, Tafsir al-Mishbah (Jakarta: Lentera Hati, 2002), h. 320.

${ }^{7}$ M. Quraish Shihab, Jilbab; Pakaian Wanita Muslimah Pandangan Ulama Masa Lalu dan Cendikiawan Kontemporer, h. 249.
} 
menutupi kepala, leher dan dada. ${ }^{8}$ Dapat ditarik kesimpulan dari makna etimologi jilbab, bahwa banyak para ahli berbeda-beda pandangan dalam makna jilbab. Dan jilbab pada umumnya adalah pakaian lebar, longgar, dan menutupi seluruh bagian tubuh. Berdasarkan perintah Allah untuk memakai jilbab QS alAḥzāb/33: 59, QS al-Nūr/24: 31 dan QS al-A'rāf/7: 26.

Jilbab sebagai sebuah pakaian penutup kepala, ternyata memiliki sejarah yang cukup panjang, bahkan kemungkinan bukan hanya dominasi umat Islam semata. Jilbab atau hijab merupakan bentuk peradaban yang sudah dikenal berates-ratus tahun sebelum datangnya Islam. Ia memiliki bentuk yang sangat beragam. Hijab bagi masyarakat Yunani memiliki ciri khas yang berbeda dengan masyarakat Romawi. Demikian pula halnya dengan hijab pada masyarakat Arab pra-Islam. Ketiga masyarakat tersebut pernah mengalami masa keemasan dalam peradaban jauh sebelum datangnya Islam. Hal ini sekaligus mematahkan anggapan yang menyatakan bahwa hijab hanya dikenal dalam tradisi Islam dan hanya dikenakan oleh wanita-wanita muslimah saja. Dalam masyarakat Yunani, sudah menjadi tradisi bagi wanita-wanitanya untuk menutup wajahnya dengan ujung selendangnya, atau dengan menggunakan hijab khusus yang terbuat dari bahan tertentu, tipis dan bentuknya sangat baik. ${ }^{9}$ Demikian pula pada masyarakat Arab pra-Islam, dalam syair-syair wanita-wanitanya dijumpai istilahistilah khusus yang kesemuanya mengandung arti yang relatif sama dengan hijab. Di antara istilah-istilah yang sering mereka gunakan adalah niqā b, khimāar, qinā, khaba , dan khadr. ${ }^{10}$ Bangsa Arab pra-Islam mewajibkan para wanitanya berhijab karena menganggapnya sebagai tradisi yang harus dilakukan. Dan ketika Islam datang, mengesahkan tradisi baik tersebut. Perintah kewajiban memakai jilbab dalam Islam mendapatkan legitimasi setelah turunnya al-Qur'an surah al-Nūr/24: 31 dan surah al-Aḥāb/33: 59. Sehingga berdasarkan kedua ayat tersebut kemudian peristilahan mengenai penutup kepala dikenal dengan nama khumūr dan jaläbib, keduanya dalam bentuk jamak.

\section{B. Hukum Islam}

Secara etimologi kata hukum الحكم berarti المنع yakni mencegah. Adapun secara terminologi, menurut mayoritas ulama mendefinisikan hukum sebagai tuntuan Allah swt yang berkaitan denga perbuatan mukallaf, baik berupa tuntutan, pilihan, atau menjadikan sesuatu sebagai sebab, syarat, penghalang,

\footnotetext{
${ }^{8}$ Ensiklopedia Hukum Islam Jilid III (Cet. V; Jakarta: PT Ichtiar Baru van Hoeve, 2001), h. 820 .

${ }^{9}$ Muhammad Farid Wadji, Dā'irāt al-Ma'ārif al-Qarn al- 'Isyrīnn(Jilid III; Beirut: Dār alMa'rifah, 1991), h. 335.

${ }^{10}$ Abdur-Rasul Abdul Hasan al-Ghaffar, Wanita Islam dan Gaya Hidup Modern, terj: Bahruddin Fanani (Bandung, Pustaka Hidayah, 1995), h. 41.
} 
sah, batal. rukhshah atau 'azimah. ${ }^{11}$ Hukum Islam sebagai suatu rangkaian kata telah menjadi bahasa Indonesia yang hidup dan terpakai, namun bukan merupakan kata yang terpakai dalam bahasa Arab, dan tidak ditemukan dalam alQur'an; juga tidak ditemukan dalam literatur berbahasa Arab. Karena itu kita tidak akan menemukan artinya secara definitif. Bila kata hukum dihubungkan kepada Islam, maka hukum Islam akan berarti: seperangkat peraturan berdasarkan wahyu Allah dan sunah Rasul tentang tingkah laku manusia mukallaf yang diakui dan diyakini mengikat untuk semua yang beragama Islam. ${ }^{12}$ Jilbab asal perintahnya wajib berupa perintah furu'iyyah (cabang-cabang agama) yang juga pemakaiannya setidaknya didukung oleh kaidah

Salah satu dalil dan metode yang digunakan dalam penggalian hukum Islam adalah al-Dzari'ah. Secara etimologi, dzari'ah (الذريعة) berarti "jalan yang menuju kepada sesuatu." Ada juga yang menghususkan pengertian dzari'ah dengan "sesuatu yang membawa kepada yang dilarang dan mengandung kemudaratan." Akan tetapi, Ibn Qayyim al-Jauziyah (691-751 H/1292-1350 M./ahli fikih Hanbali), mengatakan bahwa pembatasan pengertian dzari'ah kepada sesuatu yang dilarang saja tidak tepat, karena ada juga dzari'ah yang bertujuan kepada yang dianjurkan. ${ }^{13}$ Oleh sebab itu, menurutnya, pengertian dzari'ah lebih baik dikemukakan yang bersifat umum sehingga dzari'ah mengandung dua pengertian, yaitu: yang dilarang, disebut dengan sadd aldzari'ah (سد الذريعة) dan yang dituntut untuk dilaksanakan, disebut fath aldzari'ah (فنتح الذريعة).

Tujuan penetapan hukum secara sadd al-dzari'ah ialah untuk memudahkan tercapainya kemaslahatan atau jauhnya kemungkinan terjadinya kerusakan atau terhindarnya diri dari kemungkinan perbuatan maksiat. Hal ini sesuai dengan tujuan syariat menetapkan perintah-perintah dan menghentikan larangan, ada yang dapat dikerjakan secara langsung da nada pula yang tidak dapat dilaksanakan secara langsung, perlu ada hal yang dikerjakan sebelumnya.

Berdasarkan uraian di atas, maka dapat disimpulkan bahwa sadd al-dzari'ah dapat dijadikan hujjah dalam menetapkan hukum dengan syarat tidak bertentangan dengan nash, tidak menghilangkan kemaslahatan serta tidak mendatangkan kemudharatan bagi pelakunya.

\section{METODOLOGI}

Penelitian ini menggunakan bentuk penelitian deskriptif kualitatif dengan pendekatan fenomenologi berusaha untuk memahami persepsi Polwan di Polres Baubau tentang jilbab sebagai ibadah agar dapat memahami tentang bagaimana dan apa makna yang mereka bentuk dari berbagai peristiwa dalam kehidupan

\footnotetext{
${ }^{11}$ Nasrun Haroen, Ushul Fiqh 1 (Cet.II ; Jakarta: Logos Wacana Ilmu, 1997), h. 207.

${ }^{12}$ Amir Syarifuddin, Ushul Fiqh I(Cet. III; Jakarta: kencana, 2008), h. 5-6.

${ }^{13}$ Ibn Qayyim al-Jauziyah, A 'lam al-Muwaqqi īn Rabb al-'Alamīn (Jilid III; Beirut: Dār alJail, 1973), h. 147.
} 
mereka sehari-hari. Penelitian jenis ini dianggap tepat untuk mendeskripsikan pemakaian jilbab bagi Polwan di Polres Baubau. Adapun sumber data dalam penelitian ini diperoleh langsung dari Polwan Polres Baubau. Selanjutnya metode pengumpulan data yang digunakan adalah observasi, wawancara, dan dokumentasi. Lalu teknik pengolahan data dan analisis data dilakukan melalui empat tahap, yaitu deskripsi, reduksi data, penyajian, dan verifikasi.

\section{HASIL DAN PEMBAHASAN}

\section{A. Perkap Jilbab Sebagai Pelaksana Ajaran Agama}

Jilbab merupakan penanda bagi sekumpulan hukum-hukum sosial yang berhubungan dengan Polwan dalam sistem Islam dan yang disyari'atkan Allah swt. agar menjadi benteng kokoh yang mampu melindungi kaum wanita, menjadi pagar pelindung yang mampu melindungi masyarakat dari fitnah, dan menjadi framework yang mengatur fungsi wanita sebagai pembentuk generasi masa depan. $^{14}$

Kepatuhan dalam lingkup Polri merupakan satu hal yang bernilai tinggi, dimana ia merupakan roda penggerak organisasi resmi Negara. Kepatuhan menjadi landasan setiap gerak langkah personelnya untuk mewujudkan tujuan instansi dengan memiliki kekuatan spiritual untuk dilaksanakan. Penggunaan jilbab bagi Polwan bukan lagi menjadi hal yang tabu setelah empat tahun berjalan sejak di keluarkan Perkap tentang jilbab.

Polwan di Polres Baubau memiliki alasan utama memakai jilbab yakni karena kewajiban sebagai seorang wanita muslimah dalam menaati perintah agama untuk menutupi aurat. Sebagaimana yang dikemukakan oleh Brigpol Lely Fajar Indarti, (31 tahun, Basat Intelkam Polres Baubau, Wawancara, Baubau, tanggal 10 Agustus 2018) "Sebagai wanita muslimah sudah menjadi kewajiban untuk menutup aurat sesuai dengan syariat Islam. Dengan dibolehkan Polwan berjilbab, sangat bagus dan sejalan dengan perintah agama”.

Pemakaian jilbab yang dilakukan Polwan mesti diapresiasi dan dihargai. Terlebih tidak ada intervensi ataupun paksaan dari pihak manapun. Hal ini bisa dilihat dari peraturan Kapolri tentang jilbab dan peraturan bahwa Polwan yang telah memutuskan untuk berjilbab di satuan kerja Polres Baubau sebagai anggota kepolisian, juga harus memakai jilbab di luar jam bertugas atau di ranah publik. Melihat fenomena pemakaian jilbab tentu penuh harap jilbab dijadikan sebagai bagian yang tidak terpisahkan dari kelengkapan pakaian sehari-hari. Terlebih jika pemakaiannya tumbuh di atas kesadaran individu yang sangat konsistatif. Sebagaimana yang diungkapkan Bripka Munartin Guluhi, SH., (37 tahun, Ps. Paur Rapkum Subbag Hukum Bag Sumda Polres Baubau, Wawancara, Baubau, tanggal 10 Agustus 2018) "Berjilbab atas kemauan dan kesadaran sendiri karena sebagai wanita muslimah wajib hukumnya untuk menutup aurat, jadi kami juga

${ }^{14}$ Ibrahim Abd Al-Muqtadir, Wanita Berjilbab VS Wanita Pesolek (Jakarta: Amzah, 2007), h. 29. 
Polwan wajib berjilbab. Karena dengan jilbab bisa lebih percaya diri dalam bertugas". Alasan yang seirama dengan ungkapan yang berbeda oleh Briptu Rahmiyanti Ahmad Syafiuddin, (26 tahun, Baurmintu Sat Tahti Polres Baubau, Wawancara, Baubau, tanggal 14 September 2018), "Saya berjilbab atas kesadaran diri pribadi, sebagai seorang perempuan yang telah menjadi Ibu untuk kedua anak-anak harus memberi contoh yang baik, suami menganjurkan dan sangat mendukung untuk memakai jilbab". Dukungan dari pasangan sebagai seorang Polwan dalam berjilbab memberikan nilai tersendiri terlebih jika pemakaiannya tumbuh atas kesadaran diri yang dikuatkan dengan peraturan Kapolri.

Jika dilihat dari segala bentuk pemanfaatan pemakaian bahwa perintah jilbab sebagai langkah antisipatif yang akan menimpa kaum perempuan. Urgensi menutup aurat bagi perempuan dalam bentuk jilbab dituntut ketika ia berada di ranah publik atau diantara laki-laki yang bukan mahram meskipun di dalam rumah misal terhadap tamu dan . Esensinya adalah menghindari terjadi resiko seks oleh laki-laki yang bukan mahramnya. Berjilbab bagi perempuan tidaklah sepanjang waktu, misalnya boleh menanggalkan pakaian jilbab itu ketika berada di rumahnya karena ia biasanya hanya berhadapan dengan seluruh anggota keluarganya sebagai mahramnya. Hal ini sesuai dengan ayat 31 surah al-Nur:

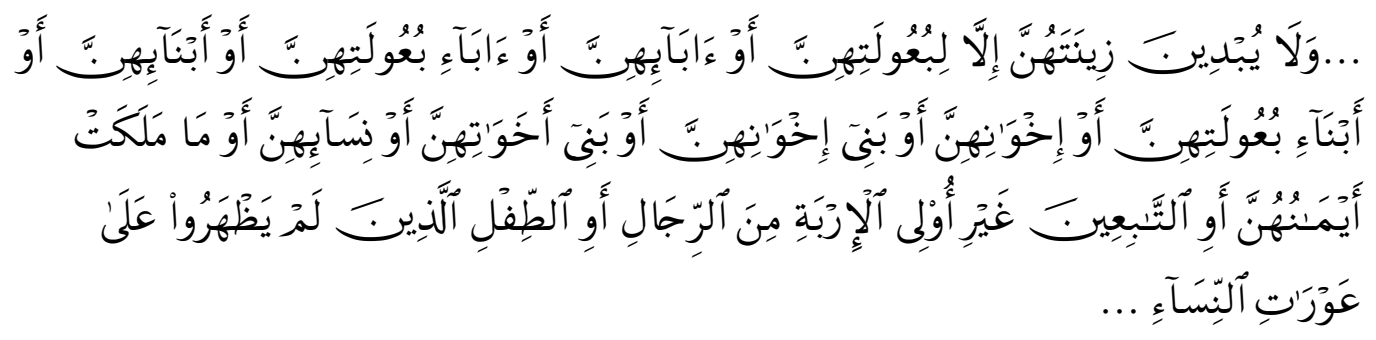

Terjemahnya:

... dan janganlah Menampakkan perhiasannya kecuali kepada suami mereka, atau ayah mereka, atau ayah suami mereka, atau putera-putera mereka, atau putera-putera suami mereka, atau saudara-saudara laki-laki mereka, atau putera-putera saudara lelaki mereka, atau putera-putera saudara perempuan mereka, atau wanita-wanita Islam, atau budak- budak yang mereka miliki, atau pelayan-pelayan laki-laki yang tidak mempunyai keinginan (terhadap wanita) atau anak-anak yang belum mengerti tentang aurat wanita... ${ }^{15}$

Brigpol Herni Dewi Sartika, (32 tahun, Bamin Keuangan Polres Baubau, Wawancara, Baubau, tanggal 10 Agustus 2018) menyatakan "Dampak positif memakai jilbab untuk melindungi diri dari pandangan laki-laki yang bukan mahram dan sebagai upaya perbaikan diri". Pernyataan serupa juga diungkapkan

\footnotetext{
${ }^{15}$ Kementrian Agama RI, Al-Quran dan Terjemahnya, h. 353.
} 
Bripda Nurlaily Putri Wakuli, (21 tahun, Ba Sat Reskrim Polres Baubau, Wawancara, Baubau, tanggal 15 Agustus 2018) "Manfaat bagi saya sendiri yakni bisa untuk melindungi diri, semakin membuat diri menjadi lebih nyaman ketika berhijab dan sebagai perempuan berjilbab kita lebih dihargai terutama oleh kaum laki-laki". Adanya upaya-upaya Polwan untuk menutupi bagian-bagian yang masih terlihat dari yang bukan mahram karena jika aurat dibiarkan terlihat rentan terjadi hal yang tidak diinginkan terlebih instansi kepolisian didominasi Polki.

Tantangan Polwan bukan hanya pada era digital tapi pada waktu-waktu tugas tertentu karena digital bisa menjadi tantangan semua pihak yang memakai. Kita berada pada perkembangan IPTEK yang sangat pesat dan canggih, dengan demikian menggunakan media sosial secara bijaksana akan mengantar pemakai tetap pada aturan dan terhindar dari suatu hal yang bersifat merugikan. Selain itu, Polwan yang berjilbab pernah merasakan tidak berjilbab, artinya mereka pernah mendapatkan perlakuan yang kurang mengenakan dari lawan jenis karena pada saat itu masih ada bagian yang belum ditutupi, seperti digombalin dan diganggu tetapi tidak sampai pada pelecehan seksual. Sejak memakai jilbab, perlakuan demikian tidak lagi dia dapatkan. Jilbab yang dipakai oleh Polwan tersebut banyak-sedikitnya sudah menutup rapat-rapat cela untuk mengundang lebih banyak lagi perlakuan tidak mengenakan dari lawan jenis.

Eksistensi Polwan dalam rangka Hari Ulang Tahun (HUT) Polwan ke 70 yang dilaksanakan pada tanggal 1-4 September 2018 di Polda Sulawesi Tenggara, tidak menganggu aktivitas dan tidak menghambat kelancaran beracara selama kegiatan baik memakai pakaian dinas lapangan (PDL) maupun pakaian dinas upacara (PDU) dan juga olah raga. Wanita berjilbab tidak selalu identik dengan seseorang yang menutup diri dari lingkungan sosialnya tapi mampu lihai dan terampil di lapangan. Hal ini membuktikan secara fisik bahwa selembar kain yang dipakai untuk menutupi seluruh kepala dan leher bukan sebagai perusak mood untuk beraktivitas tetapi bahkan bisa memberikan energik lebih, meningkatkan kinerja dan pelayanan yang baik kepada masyarakat.

Tantangan terberat sebagai Polwan adalah ketika mendapat hal yang sama dengan Polki tetapi masih mempunyai beban sosial dan budaya sebagai perempuan. Sedangkan dalam hal jilbab adalah pemakaiannya yang harus konstitatif dalam ranah publik. Pertentangan yang cukup ramai adalah kebijakan Polri tentang jilbab bagi Polwan yang saat ini telah dikeluarkan secara resmi Perkap tentang jilbab. Selain konteks agama, perbedaan ini juga dalam konteks gender, salah satunya adalah beban tugas domestik dalam keluarga yang dilakukan setelah pulang dari bertugas. Hal ini tidak terjadi pada Polki karena istrinyalah yang mengemban tugas domestik tersebut. Di sisi lain, pengertian wanita sebagai makhluk lemah merasa dibedakan dari Polki pada bagian tugas, misalnya dalam pekerjaan fisik lapangan dan jam kerja di malam hari yang dianggap tidak bisa dilakukan Polwan. Namun kenyataan tersebut, bukan untuk mendiskriminasi Polwan, justru memberikan rasa hormat dan kemuliaan kepada wanita. 
Karakter Polwan yang dianggap sangat feminim sangat menguntungkan pihak kepolisian dalam menyelesaikan kasus-kasus kejahatan dengan sentuhan kewanitaan dalam melaksanakan tugas dibanding Polki. Polwan dianggap lebih detail, rapi, rinci dan teliti serta mampu multitasking di pekerjaan dinas dan domestik keluarga sehingga mereka dinilai lebih handal mengatasi banyak pekerjaan.

\section{B. Pemakaian Jilbab Sebagai (Bernilai) Ibadah}

Dalam surah Adz-Dzāriyāt: 56 memberikan penguatan kepada manusia sebagai seorang hamba untuk senantiasa tunduk dan patuh dalam bingkai ibadah atas segala sesuatu yang telah Allah perintahkan. Dalam QS Adz-Dzāriyāt/51: 56

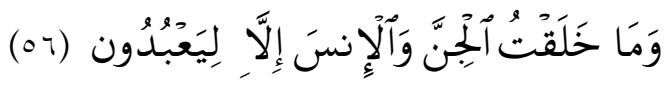

Terjemahnya:

Dan aku tidak menciptakan jin dan manusia melainkan supaya mereka menyembah-Ku. ${ }^{16}$

Tidak terjadi perselisihan antar manusia bahwa menutup tubuh merupakan fitrah manusia yang telah tertanam dalam diri meskipun panas dan dingin tetapi manusia lebih nyaman memakai pakaian walaupun hanya dinikmati oleh diri sendiri. Pada awal penciptaan manusia, Adam dan Hawa menutup aurat meski ketika itu belum ada tercipta manusia lain.

Ketika fitrah menutup aurat menjadi sasaran tarik-menarik antara akal, hawa nafsu, syubhat serta tipu daya setan, syariat hadir sebagai pedoman dan keputusan melalui nash-nash yang terdapat dalam syariat untuk sepanjang zaman. Penolong diatas penolong terjaganya seorang wanita dari segala bentuk tindakan merugikan adalah pakaian islami. Seperti upaya yang telah dilakukan oleh mayoritas Polwan. Peneliti tegaskan bahwa ibadah dalam memakai jilbab dengan niat tulus sebagai pemenuhan perintah agama akan bernilai ibadah. Namun sering kali pemakainnya dikaitkan dengan ibadah mahdah dan ghairu mahdah yang merupakan kewajiban ushulliyah (pokok-pokok agama). Sementara jilbab merupakan kewajiban furu'iyyah (cabang-cabang agama) sehingga pemakaian jilbab harus juga terlaksana ibadah mahdah dan ghairu mahdah nya.

Dalam surah Adz-Dzāriyāt/51:56 memberikan penguatan kepada manusia sebagai seorang hamba untuk senantiasa tunduk dan patuh dalam bingkai ibadah atas segala sesuatu yang telah Allah perintahkan. Pelaksanakan ibadah seperti: sholat, zakat, puasa merupakan perintah yang wajib dilakukan oleh setiap muslim sebagai rukun Islam. Namun dalam pelaksanaannya terdapat kolerasi yang sangat erat dan tidak dapat dipisahkan. Pada hakekatnya disusun sesuai dengan tingkatan kualitas wajibnya, shalat lebih utama dibanding zakat setelah syahadat sebagai dasar amalan, zakat lebih utama dibanding puasa ramadhan. Jilbab pun demikian, berdasarkan perintah Allah untuk memakai jilbab bagi setiap wanita

\footnotetext{
${ }^{16}$ Kementrian Agama, Al-Qur'an dan Terjemahnya, h. 523.
} 
muslimah maka pelaksanaanyapun bernilai ibadah di sisi Allah dan selain itu pula untuk membuktikan keimanan seorang wanita di hadapan Allah.

Menurut Bripda Nurul Poniyanti perintah menutup aurat merupakan perintah bagi semua wanita muslimah yang ada di seluruh penjuru dunia yang bertujuan agar wanita merasa nyaman dan tidak ada gangguan yang diterima dari pihak non mahram, tidak hanya meraih manfaat itu saja tetapi banyak manfaat. Selain itu, sebagai bentuk ketaatan dan kepatuhan menjadi hamba untuk mengharapkan nilai ibadah.

Polwan dengan segala kewajibannya menjalankan seluruh tugas yang diemban, memposisikan diri sebagai wanita yang berwibawa sekalipun Polwan yang memakai jilbab dituntut untuk selalu tampil anggun dan professional sesuai ketentuan yang berlaku. Jilbab bukan penghalang untuk bisa tampil terbaik bahkan justru mengundang terjaganya kehormatan sebagai wanita muslimah. Seperti yang dinyatakan oleh Bripka Munartin Guluhi, (37 tahun, Ps. Paur Rapkum Subbag Hukum Bag Sumda Polres Baubau, Wawancara, Baubau, tanggal 10 Agustus 2018) "Alhamdulillah sampai saat ini, tugas-tugas kami sebagai Polwan berjalan dengan lancar tanpa ada hambatan. Kami bertugas di lapangan merasa berwibawa dan kami nyaman dalam bertugas untuk menjaga kehormatan sebagai wanita muslimah".

Penilaian jilbab sering dikaitkan dengan ibadah mahdlah dan ghairu mahdlah. Jika sudah memakai jilbab maka ibadah mahdlah dan ghairu mahdlahnya seharusnya dijalankan, begitupun sebaliknya karena segala perintah Allah wajib untuk ditunaikan. Islam memerintahkan untuk ditunaikan segala perintah baik perintah ushuliyyah (pokok-pokok agama) dan perintah furu'iyyah cabang-cabang agama). Jilbab bukan tentang suka atau tidak suka, pribadi baik atau pribadi kurang baik, dan jilbab bukan tentang sekedar pilihan tapi jilbab tentang perintah wajib yang harus dilaksanakan sehingga pelaksanaan perintah yang lain akan terpenuhi bersama. Dahulu, Perempuan berjilbab lebih dipandang masyarakat sebagai sosok yang rajin beribadah, namun sekarang tidak semua demikian. Tidak dapat dipungkiri bahwa pergeseran makna jilbab sudah terjadi yakni menjadi trend fashion, style dan atau kebutuhan lain namun posisi jilbab tetap dalam perintah yang sangat mulia, konsumer jilbablah yang akan membawa penilaian ke arah yang baik atau sebaliknya.

\section{Jilbab Perspektif Metodologi Hukum Islam}

Menurut abu zayd, syariat menunjuk kepada kaidah-kaidah dan prinsipprinsip universal (al-qawā 'id wa al-mabādi' al-kullāyah) yang diwahyukan oleh Allah swt. sedangkan konsep fikih menunjuk kepada ijtihad-ijtihad manusia yaitu 
para ahli fikih dalam mengatualisasikan prinsip-prinsip fikih ke dalam realitasrealitas aktual pada berbagai waktu dan tempat. ${ }^{17}$

Baik teori hukum maupun penerapan hukum jilbab di tengah-tengah umat Islam di berbagai belahan dunia, tidak terkecuali di Indonesia, ternyata berbedabeda. Ditemukan banyak kalangan perempuan muslim menganut prinsip mutahajjibah sehingga seluruh tubuhnya ditutup pakaian. Sebagiannya lagi menutup tubuhnya dengan pakaian kecuali muka dan telapak tangan. Kenyataan ini dipastikan berada ranah hukum fikih. Salah satu karakteristik hukum fikih adalah tersinyalir mengandung perbedaan pendapat.

Ulama kelompok yang berpendapat bahwa seluruh tubuh wanita aurat ialah Al-'Ușaimîn menyatakan secara tegas bahwa berjilbab dan menutupnya seorang wanita atas wajahnya dari laki-laki asing merupakan perkara yang wajib. ${ }^{18}$ Al-Maudūdi menafsirkan kata jalābib, yang merupakan jamak dari jilbab dengan pakaian yang besar, khimār atau rida' dan berpendapat bahwa ayat tersebut turun khusus tentang menutup wajah. Dan dari ayat ini juga dapat dipahami bahwa wanita keluar rumah diharuskan mengenakan pakaian yang tertutup rapat seperti dengan menggunakan khimār atau niqāb, yang merupakan penanda bahwa mereka adalah wanita yang mulia dan agar mereka tidak diganggu oleh orang jahat, sedangkan ulama kelompok yang berpendapat bahwa seluruh tubuh wanita aurat kecuali wajah dan telapak tangan, di antaranya Ibnu Taimiyah mengatakan bahwa pada dasarnya, ayat tentang jilbab itu berkaitan dengan wanita ketika keluar dari tempat tinggalnya. Sedangkan ayat tantang hijab itu berkaitan dengan wanita ketika berbicara (dengan laki-laki yang bukan mahramnya) di tempat tinggalnya. ${ }^{19}$ Imam Al-Qurthubi dalam tafsrinya yang berjudul Tafsir Qurthubi menjelaskan jilbab adalah pakaian yang menutupi seluruh tubuh kecuali wajah dan telapak tangan. Ada juga yang berpendapat bahwa jilbab adalah baju jubah atau pakaian longgar bagi perempuan yang menutupi seluruh anggota tubuh atau aurat perempuan. ${ }^{20}$ Mereka sepakat bahwa mengenakan jilbab merupakan perintah, khilafiyah dalam kelompok ini hanya timbul pada hukum apakah perempuan wajib menutup wajah atau membiarkan terbuka.

Ulama kelompok yang tidak mewajibkan jilbab beberapa diantaranya Qāsim Amīn, Gamāl al-Bannā, Muḥammad Sa'̄̄d al-Asymāwīe M. Quraish Shihab menilai bahwa pakaian bukanlah termasuk ajaran Islam yang bersifat ta'abbudi melainkan dengan muamalat dan tradisi yang dapat ditemukan illatnya (alasan pembenarannya). Tetapi perbedaan pendapat tersebut tidak untuk saling

\footnotetext{
${ }^{17}$ Nasr Hamid Abu Zayd, Dawa'iru al-Khauf: Qira'atu fi Khitabi al-Mar'ati (Beirut: alMarkazu as-Staqofi al-‘Arabi, 2000), h. 187.

${ }^{18}$ Muhammad bin Sālih al- 'Usaimîn, Risalah al-Hijab (Bairut: Maktabah al-Waqfiyyah, 2009), h. 5.

${ }^{19}$ Taqiyyuddin Ahmad bin Taimiyah, Majmu' Fatawa, Jilid XV (Cet. IV; Beirut: Dār alWafā', 1432 H/2011 M), h. 448

${ }^{20}$ Badriyah, Yuk, Sempurnakan Hijab!. (Kartasura: AISAR Publishing, 2014), h. 9.
} 
kafir mengkafirkan, karena al-Qur'an tidak secara jelas menetapkan batas aurat wanita. Yang terpenting adalah pakaian sopan, tidak bertabarruj, tidak transparan dan tidak membentuk lekukan tubuh.

Ternyata tata cara menutup aurat perempuan di kalangan ulama, khususnya para fukaha telah terjadi perbedaan pendapat. Ini salah satu bukti menutup aurat bagi wanita telah masuk dalam ranah fikih yang membuat umat Islam sulit mengelak dari perbedaan. Tentu perbedaan tersebut lahir dari metode memahami teks-teks al-Qur'an tentang jilbab bagi wanita. Bagi yang telah memakai jilbab untuk tetap konstitatif dengan berpegang kepada pendapat yang mewajibkan jilbab dan menyikapi pendapat ulama yang tidak mewajibkan jilbab dijadikan sebagai sebatas ilmu pengetahuan. Berangkat dari teks-teks suci alQur'an dan al-Sunnah hukum jilbab bagi wanita adalah syariat, namun dalam bentuk dan tatacaranya adalah fikih.

Keharusan berjilbab bagi wanita setidaknya didukung oleh kaidah:

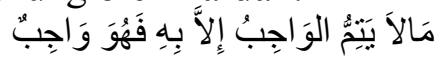

"apabila suatu kewajiban tergantung kepada sesuatu yang lain, maka sesuatu yang lain ini pun wajib dikerjakan"

\section{PENUTUP}

\section{A. KESIMPULAN}

Secara fenomenologi, penggunaan jilbab bagi Polwan saat ini tidak hanya dipandang perspektif agama saja yakni pelaksanaannya bernilai ibadah, meskipun tumbuh atas kesadaran diri dan berdasarkan teks-teks suci al-Qur'an dan alSunnah, namun ia juga mendapatkan dukungan peraturan Kapolri. Sejumlah inspirasi berhasil merubah gaya berpakaian dinas dengan melihat seragam Polwan Aceh yang tetap anggun, berwibawa dan professional bertugas. Alasan stori unik Polwan akhrinya turun menjadikan terpakainya kain untuk menutup kepala dan leher, di antaranya Polwan salah memotong rambut (pendek).

\section{DAFTAR PUSTAKA}

Ahmad bin Taimiyah, Taqiyyuddin. Majmu' Fatawa Jilid XV, Cet. IV; Beirut: Dār al-Wafā', 1432 H/2011 M.

Al-Ghaffar, Abdur-Rasul Abdul Hasan. Wanita Islam dan Gaya Hidup Modern, Bandung, Pustaka Hidayah, 1995.

Al-Jauziyah, Ibn Qayyim. A'lam al-Muwaqqi īn Rabb al-'Alamīn Jilid III, Beirut: Dār al-Jail, 1973.

El-Guindi, Fedwa. Jilbab Antara Kesalehan, Kesopanan Dan Perlawanan, Jakarta: Serambi, 2006.

Ensiklopedia Hukum Islam Jilid III, Cet. V; Jakarta: PT Ichtiar Baru van Hoeve, 2001. 
Farid Wadji, Muhammad. Dā 'irāt al-Ma'ārif al-Qarn al-'Isyn̄nn, Jilid III; Beirut: Dār al-Ma'rifah, 1991.

Hamid Abu Zayd, Nasr. Dawa'iru al-Khauf: Qira'atu fi Khitabi al-Mar'ati, Beirut: al-Markazu as-Staqofi al-'Arabi, 2000.

Haroen, Nasrun. Ushul Fiqh 1, Cet.II ; Jakarta: Logos Wacana Ilmu, 1997.

Ibrahim Abd Al-Muqtadir, Wanita Berjilbab Vs Wanita Pesolek, Jakarta: Amzah, 2007.

Kementrian Agama RI, Al-Quran dan Terjemahnya, Jakarta: Samad, 2014.

Muhiydin, Muhammad. Membela Lautan Jilbab, Yogyakarta: Diva Press, 2008.

Sālih al- 'Usaimîn, Muhammad bin. Risalah al-Hijab, Bairut: Maktabah alWaqfiyyah, 2009.

Shihab, Quraish. Jilbab Pakaian Wanita Muslimah; Pandangan Ulama Masa Lalu dan Cendikiawan Kontemporer, Jakarta: Lentera Hati, 2004.

Shihab, Quraish. Tafsir al-Mishbah, Jakarta: Lentera Hati, 2002.

Syarifuddin, Amir. Ushul Fiqh I, Cet. III; Jakarta: kencana, 2008. 